https://doi.org/10.18485/poet_srp_real.2018.ch3

\author{
Драгана Б. Вукићевић ${ }^{1}$ \\ Универзитет у Београду \\ Филолошки факултет
}

\title{
ПАРОДИЈА У СРПСКОЈ РЕАЛИСТИЧКОЈ ПРОЗИ
}

У раду се анализирају три аспекта пародије А) ужи реторички (текст-антитекст, негативна компарација, антитеза, контраст) Б) књижевноисторијски (однос према ранијим традицијама: пародирање сентименталистичке литературе - немачке чувствителности, „сладког стила”, вертеризма; пародирање - романтичарских конвенција (романтизација љубави, нације, вере); пародирање реалистичких конвенција; ц) шири културолошки аспекти пародије (напуштање имитативних модела „више” културе).

Кључне речи: пародија, српски реализам, цитатност, стилизација.

Полазећи од теза когнитивних наратолога насталих на теоријској платформи естетике рецепције да у менталној мапи читалаца књижевна дела нису острва већ умрежени текстови и да су начини њиховог умрежавања динамични па је тешко стабилизовати и фиксирати релације између њих, у овом раду ћемо се задржати на оном типу умрежавања у којем су унутар текста јасни „знаци прије-

\footnotetext{
${ }^{1}$ dragana.vukicevic67@gmail.com
} 
ма" другог текста. Присуство текста у тексту је тема која је интригирала проучаваоце књижевности и рефлексе њихових промишљања пратимо од античких теорија, преко ренесансних теорија подражавања, естетике рецепције, бартовских обрачуна са ауторитетом аутора, све до теорија о интертекстуалним и цитатним релацијама између текстова.

Не улазећи у теоријску генезу овог проблема, задржавамо се на опозитним моделима цитатних релација, једни су илустративни, други илуминативни ${ }^{2}$. У раду Дубравке Ораић Толић у првом типу цитатности „на плану семантике доминира начело мимезе, аналогије, метафоричности, и адеквације (цитатна имитација), на плану синтактике начело субординације властитога под туђе, на плану прагматике статична оријентација на познато читатељево искуство, а на плану културне функције начело репрезентације туђега текста и туђе културе." (Ораић Толић1990: 2015) Ауторка их сматра карактеристичним за средњевековну књижевност која је настајала у орбити једног текста Библије, за књижевност хуманизма и ренесансе, као и за класицизам и оријентисаност на античку књижевност као узорит тип књижевности (довољно је, на пример, у српској књижевности погледати само жанровска или версификацијска пресликавања античких образаца у поезији Лукијана Мушицког). Српска романтичарска књижевност, како лирска, тако и драмска, у великој мери је настајала на фолклорном предлошку, померајући усмену књижевност из поља периферне игнорисане књижевности коју је често пратила естетика негације - у поље узоритих текстова

${ }^{2}$ О разликама између ова два типа цитатности опширније у:

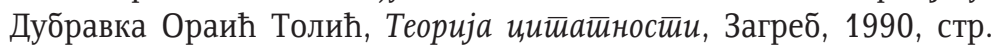
43. 
(писање устаничких биографија, на пример, по узору на Плутраха и сл.).

Реализам је стилска формација која је пружала највећи отпор канону текста. Све што је упућивало на текстуалне конвенције/клишее требало је минимализовати и успоставити најмању могућу разлику између живота и текста који је сав био у напору имлицитне поредбе као у животу. Књижевни текстови су се интензивно пунили фактоцитатитима - подржавањима судских молби, жалби, рецептима, говорним жанровима (удварања, разговори за столом, свађе, наговарања...). ${ }^{3}$ У критици се као естетска предност истицала миметичка уверљивост текста - препознавали прототипови, процењивала „природност” језика или мотивација која се доводила у везу са вероватноћом делања јунака у реалном свету у пресликаним хипотетичким ситуацијама. Ипак, и реалистички текст је текст који не може својом телеологијом да промени своју онтологију - и он је текст умрежен у друге текстова, у једном динамичном дијалогу са најразличитијим текстовима: усменом књижевношћу (особито струја фолклорног реализма), са научним текстовима (рефлекси програмског реализма у делима реалистичких писаца), са текстовима других (пре)реалистичких или постреалистичких писаца. У реалистичким текстовима похрањени су и знаци „негативног пријема" другог текста. Већ у Поіллеgу на књижесииво 1857, Игњатовић истиче потребу за променом рецептивног кода и антиципира свој пародијски однос према имитативним књижевностима - класицистичкој (јер Тибар не тече Србијом) и немачко-сентименталистичкој. У наставку рада

\footnotetext{
${ }^{3}$ У прози Јована Грчића Миленка покушава се минимализовати разлика између оног који пише и оног коме се нешто дешава покушајем (немогућим) укидања временске дистанце између њих.
} 
задржаћемо се само на аспектима негативног пријема покушавајући да у пародији препознамо логику те негације.

Пародију смо издвојили као битну цитатну релацију у реалистичким текстовима јер се управо њоме „удара” на ауторитет текста. Ипак, не можемо а да не приметимо њен унутрашњи парадокс - она није само полемички дијалог са другим текстом, она је и нека врста тродуплог текста, текста са „дуплим дном" који истовремено ревитализује и оспорава „туђи текст” и ствара нови. Пародија припада илуминативном типу цитатности који је, по мишљењу Дубравке Ораић Толић, „инверзија првог (илустративног, прим Д.В.) и остваривао би на плану семантике начело очуђења, контраста или хомологије, метонимичности и креације нових смислова на подлози старих (цитатна полемика и цитатни дијалог), на плану синтактике начело координације међу равноправним партнерима, на прагматичком плану динамичну оријентацију на ауторово непознато виђење културне традиције које разбија уходане рецептивне навике, а на плану културне функције начело презентације властитог текста и властите културе без обзира и често усупрот туђим текстовима и туђој култури" (Ораић Толић 1990: 44).

Иако смо истакли да пародија архивира знаке негативног пријема туђег текста, релацијске везе између текстова које се њоме успостављају много су динамичније. Већ је Тињанов писао о двопланској природи пародије, о веселости пародије, о креативној игри аутора с другим текстом. У студији Пароguja Новица Петковић издваја посеб̆о стање „интимне наклоности” пародичара према тексту који пародира.

Текст који се пародира прво се усваја, опонаша, речју - воли. Неретко су аутори били пасионирани читаоци, чак и опонашатељи литературе коју су касније пародирали или литерализовали као пример своје читалачке заблуде 
(Доситеј као посвећени читалац житија или Стерија као не само посвећени читалац, већ у раним романима опонашатељ Видаковићевог стила писања). Ова врста присности са текстом који се пародира (од којег се дистанцира) нужна је јер се тај текст мора у новом контексту „оживети” - он мора бити препознат од стране читаоца. На овом месту Тињанов успоставља разлику између стилизације и пародије. ${ }^{4}$ Пародирани (туђи) текстови се јављају као напуштени љубавници. У првом тренутку - они се опонашају, већ у другом - пародирају. Стилизовани текст је текст који се не напушта (поље привлачења је интензивније од поља одбијања). Код реалистичких писаца примећујемо да је избор теме у великој мери одређивао и избор цитатне релације - у (псеудо)историјској прози, на пример, присутније је била стилизација, а у друштвено реалистичкој прози - пародија.

За разлику од стилизације, пародија подразумева рецепцијски преокрет. Њега дефинишемо као поступак

${ }^{4}$ Проучавајући реторички потенцијал пародије, Тињанов истиче да је треба разликовати од стилизације: „Стилизација је блиска пародији. И једна и друга живе двојним животом: иза плана дела налази се други план, стилизован или пародиран. Али у пародији је обавезан неспоразум обају планова, њихов поремећај... Приликом стилизације тог неспоразума нема, напротив, постоји међусобна подударност оба плана: стилизирајућег и стилизованог" (Тињанов 1991: 165). У наставку Тињанов закључује: „Ипак је од стилизације до пародије - корак (рекли бисмо пре, искорак, прим. Д.В.) комично мотивисана или пренаглешена стилизација претвара се у пародију" (Тињанов 1991: 165). Примећујемо готово заједничу црту писаца пародичара да пре или паралелно са пародијским текстовима пишу текстове у којима подражавају одређен популаран стил писања. Примере „стилизације” налазимо у Доситејевој раној фази када пише под јаким утицајем црквене књижевности или у Сремчевим причама староставним. Ове облике „цитирања” других текстова треба разликовати од пародије. 
рефокусирање и деконтекстуализације туђег текста који почива на изразитој ауторској поетичкој ауторефлексији. Следећи рад Маје Херман Секулић Ка новом разумевању üapoguje (1989), поетичке ауторефлексије тумачимо као „развијену књижевну историјску свест писаца пародичара о могућностима традиције којој припадају, односно медијума у коме се изражавају". Захваљујући овој свести они успевају прво да стваралачко опонашају, а потом да се критички удаље од текста који пародирају. Сукоб, прекид, прелом, у семантичком пољу смо речи којима се често описује пародија. Она је поуздан фактор динамичности традиције, препознавања „разлика” и футуристичке оријентисаности према другачијој рецепцији.

Зависно од тога који тип литературе је био у функцији „текста који се пародира”, дијахронијски сагледавамо пут српске књижевности. Издвајамо неколико приповедних калупа (пародијских мета) које су се појавили у прози српских реалиста (реч калуп није случајно изабрана - преузета је из Стеријиног романа у којем наратор у дијалогу са читатељком каже: „књига није чизма да се мора по калупу правити" (Стерија 1998: 49). У наставку рада пародију ћемо тумачити у ширем значењу речи не правећи дистинкцију у односу на травестију (у Речнику књижевних иермина травестија се и дефинише као „облик пародирања" 1986: 829).

Прва мета пародија (редослед није битан, више је дистинктиван): КЛАсицистичКИ КАЛуП.

Класицистички калуп се стабилизовао системом школства. Још у тексту Како су нас васиииеиавали у „исповест једног правитељственог питомца” која је „само једна варијација од исповести једног целог српског колена", Светозар Марковић пише: „Ја сад мало памтим шта сам учио, али у то доба знам добро да сам изучавао та правила и да сам их примењивао свуда, где год сам могао: било то 
у писму матери, било то у лекцији опште историје" (1937: 158). У ироничном контексту Марковић наставља своју анализу: „Много су нам добра донеле реторика и поезија. Саздале су нам оне романисте и новелисте који су писали романе и новеле из народног живота, а нису нимало знали народ. Али зато су они знали како треба изабрати „фабулу”, како стројити „заплет” и како га размршавати итд. Саздали су нам појете који су певали о љубави коју нису осећали; певали о крви и јатаганима - једном речи о свему што нису знали. Али зато су знали - шта је фигура, шта тропа и шта метафора; шта су то јамби и шта трохеи и које су строфе и с какавим сликом најблагозвучније." (Марковић 1937: 160)

У прози Ј. Игњатовића и С. Сремца често се класицистички калуп пародира или карикира поступцима деконтекстуализације/деградације античких божанстава и јунака и њиховим „спуштањем” у раван нискомиметских јунака. Стварају се комична поређења у којима су елементи који се пореди потпуно неповезани - што је само поређење неприкладније и туђ текст више онеобичен, ефекат комичног је већи.

На пример, у Ивковој слави неприлично понашање гостију приповедач доводи у везу са сценом из Oguceje:

Од Хомерова доба није ваљда така зулума било, него онда у Итаци и сада у Ивковој кући 23, 24. и 25. априла. Јер кардаши су се у Ивковој кући разбаршарили не друкче него као оно негда Пенелопини просци у Улисовој, па се ти синови часте! И да је за Ивка на већу бруку ово упоређење - Пенелопини просиоци су се бар частили за одсутна Улиса, па то и којекако; али ови за жива и присутна Ивка, а то тек она брука.

У Пой Ћири и йой Сйupu, освајање учитеља, пореди се са Цезаровим тријумфом: 
Госпоја Перса била је задовољна, блажена! Још код поп Спириних могла је већ видети како се ствар срећно упутила, и да је нешто знала латински, могла је још тамо рећи оно старо римско: Veni, vidi, vici!

Индикативно је и поређење панорамских представа за које публика није заинтересована: „И панорама остаде без деце као Ниоба" (Сремац, Пуйујуће gрушишво, б.г. 255). У сваком од наведених комичних поређења ми препознајемо знаке „негативног пријема” текста - његово пародијско унижавање поређењем по сличности на месту где се једино разлике могу успоставити (узвишено и ниско, озбиљно и тривијално, трагично и водвиљско и сл.).

\section{ДрУГа МеТа - ПАТЕТИЧАН КАЛУП}

Патетичан модел писања нарочито је био развијен у оквирима сентименталистичке и романтичарске књижевности. Игњатовић га је у чланку Поїлеg на књинесиво везивао за утицај немачке литературе сматрајући да „чувствителност” коју је развијала оваква литература не одговара српском духу. Овај тип литературе критиковао је и Светозар Марковић за којег је наша савремена поезија „смеша љубавних изјава, фантастичних сцена, празних фраза и смешних будалаштина" (Марковић 1937: 187).

Мали је број реалистичких писаца који су одолели пародичној контекстуализацији растављених љубавника, уцвељених јунакиња, неискрених патриота... Паралелно ће се пародирати популарана, преводна литература која је неговала „болећивог читаоца” и то у време када је српска литература, на трагу идеја Светозара Марковића, развијала другачију телеолошку опцију и афирмисала идеју „новог човека” (новог читаоца) окренутог утилитарном схватању књижевности. 
Навешћемо неколико примера пародирање патетичног модела:

У Игњатовићевим романима често се понавља хронотопична ситуација коју бисмо могли назвати „несрећно заљубљени јунак посећује гробље”. Индикативан је начин како се описују јунакиње које је „туга убила”. У роману Тр-

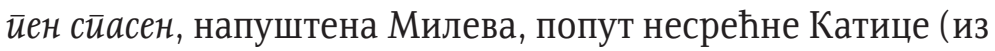

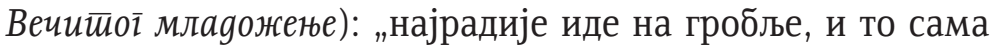
ујутру рано, тек што се сунце роди ...Тражи гробове умрлих девојака и младића. Седне на таки гроб, промишља о животу у младости, бере гробско цвеће и склапа га у китицу. Види капљицу на цвету, то је од росе, а роса испарење гробско, задах душе несретне девојке коју је драги изневерио. У том росном огледалу огледа се Милева, дивно изгледа, па опет као кроз призматично стакло чини јој се да види лик лаћмана, па стидљиво поглед натраг тргне, па она очита „оченаш” и још коју молитву, скупи цвеће, уздахе и оде" (Игњатовић 1981: 97). ${ }^{5}$

Опис Милевиног гробљанског расположења није пастиш мелодрамске прозе већ текст, који, следећи Лотмана, дефинишемо као текст провокатор. Њиме се управо пародира мелодрамски сиже и сентименталистички манир писања. Читалац не пати са јунакињом, он „с наратором” демаскира њену тугу. Коментар се јавља као разоран метатекст који уништава „туђи текст” - разобличава патетичан стил писања.

У Сремчевој приповеци Иgеал већ у заглављу прве главе пародирају се дводелни наслови и клишетизирани садржаји прича о идеалним, али растављеним љубавницима: Глава ирвва. У юој је слуиајни и срећани йочетиак и насилни

\footnotetext{
${ }^{5}$ О маскама несрећно заљубљених сам писала у раду: љубав іаланйома или љубав на бияермајерски начин У: 150 година од доласка Јакова Игњатовића у Даљ (1863-2013), зборник радова с међународног научног скупа; Даљ, 2014: 80-108.
} 
и несрећни крај јеgне чисте ияеалне љубави или: сиромашни

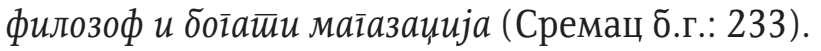

Сремац не пародира песму Лазе Костића Мuнаgup (песма је о љубави наимара Минадира и краљеве ћерке Валадила) - она се дословно цитира. Пародија настаје њеном деконтекстуализацијом па се више не тумачи она већ они који је читају и начин како је разумеју и тумаче. Интерпретација постаје једна врста пародијског омотача јер „после такве лектире, шта је природније него да се једно другом заклињу на вечиту верност, на љубав до гроба, па чак и преко гроба" (Сремац б.г.: 238).

Писмо несрећног љубавника упућено противнику да не раставља оне који се воле, поступком комичног снижавања се реинтерпретира. Пародирају се околности у којима се чита писмо (док му шпедитер чита писмо, магазаџија сече роткву и брижљиво соли сваки режањ); Комично се интерпретирају клишетизиране изјаве вечите љубави:

- Шта вели? Вечита љубав! „Пиринчана” на Дорћолу, ем онакав тврд материјал - па се баталила, нема је; а они ми причају ту за некакву љубав. (Сремац б.г.: 241)

Комично се интерпретира и бол унесрећених љубавника:

- А шта кажу у писму: оће да им препукне срце! Оће то кој га не познаје! Пуца срце тако лако!... Може да пукне лонац, кестен печен, цилиндер од лампе, и нос може да пукне - ама да срце пукне... (Сремац б.г.: 241).

Нити су Сремчеви љубавници идеални, нити је њихова љубав вечна - Сремац прибегава комичном контрастирању Језика (патетичне тираде, заклетве на вечну љубав, на спајање на оном свету), Ситуације и Јунака. Његови јунаци (јер тако пише и тако треба да буде) - не мршаве од љубавне патње, нити се усамљено шетају по ружичњаци- 
ма, нити размишљају о бесмислу свог живота... Иако текст „призива” други, туђи текст (сентименталистичка прича о растављеним љубавницима), он га заправо пародира.

У приповеци Иgеал напуштени јунак се не убија, четвртог дана му се враћа апетит, а идеална љубавница из младости („Где је она жена?”) постала је брката жена: „Она има бркове!!! Јелена је брката жена! Ах каква нечувена несрећа").

Сремац пародира сусрет растављених па поново спојених љубавника и коментаром приповедача додатно појачава нову, литерарно „неописиву”, неподношљиву позицију свог јунака којег идеална љубавница (брката жена) гледа: „Тако му је био чудан и необичан и тај њен поглед и ово његово осећање. То осећање још нигда ни у којој књизи није описано, зато се ни ја не усуђујем да га описујем" (Сремац б.г. 265). Или: „Још се ниједан роман и ниједна драма или трагедија није овако свршила. Баш је доста читао, али да се овако заврши једна чиста и идеална љубав - то није још нигде прочитао" (Сремац б.г. 272)

Нежна идеална љубавница којој се јунак заклања на верност до гроба и преко гроба, у реалистичком тексту трансформише се у реалистичку „Чимпеприч” - бркату жену, која док председава пред скупум феминисткиња, у сновима прогања јунака. „Реалистичка прича” развија се на антифону Костићеве песме - као антитекст цитиран у туђем тексту - „као што оно песник вели”: 'Нема такве приповести// Од Индуса па до Нила!"' (Сремац, б.г. 279)

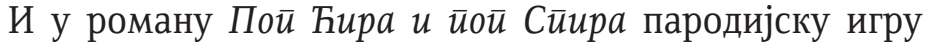
с туђим текстом, Сремац директно открива у коментару метаприповедача. Надређена приповедна инстанца се јавља као једна врста ироничног коментатора који разобличава клишетизиране атрибутизације несрећних остављених девојака: 
Јула је туговала, не смем рећи венула, јер, као за пакост, мада је била заљубљена, остала је једнако (иро-

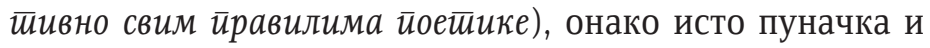
округла као и негда још кад није знала за ту, такорећи паклену, али ипак тако слатку страст" (ист. Д.В.)

Код Стевана Сремца лектира је попут маске, шифра преко које се разоткривају компензациони ефекти читања. На пример, Јован Ватра из Божићне иеченище „мало је читао ал најрадије Темеову криминалну библиотеку“; криминалистичке приче чита и мајстор Мицко све док га нова литература Житиија Алексеја человијека божија духовно не преобрази. Капетану Марјану се йрейоручује пригодна литература Ракија је убила срећу моју, али читалачко искуство не мења јунака у антиалкохоличара, Меланија чита „немецке” књиге, а Јула Љубомира у Јелисиуму, Age-

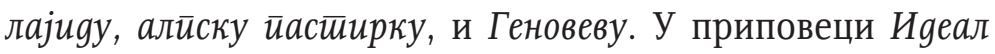
Душан Иванић упућује на неколико интертекстуалних релација: „Уз цитате из Ромеа и Јулије, Смричи Омера и Мериме, Ройсива Јанковић Сйојана, Хајнеове пјесме Палма с јуі̄a u бор са севера те Костићеве баладе Минаgир, или уз паралеле с љубавним причама у овим дјелима, љубавна историја Сремчевих јунака дјелује као права пародија" (Иванић 2007: 127). Унапред банални, јунаци који опонашају литерарне узоре постају још баналнији на фону „неадекватне” стилске матрице. Реч је о занимљивој херменеутичкој игри у којој се Сремчеви јунаци интерпретирају преко сопствене интерпретације онога што читају (што глуме), с једне стране, и у којој се, с друге стране, у ширем контексту, преиспитује одређен тип литературе као и начини њене рецепције. Читави пасуси су грађени по принципу поредбених веза којим се „аутентичан живот јунака" преводи у литерарне фразе, клишее. Јунаци који своју недраматичну стварност компензују литерарним уз- 
буђењима истовремено су чеховљевски поетски у трагичности своје неостварености и гогољевски банални у својој остварености. Сами по себи нису ни довољно трагични, ни довољно озбиљни, ни довољно жртве, ни довољно јунаци, а таквима желе бити и таквима се кроз своје литерарне двојнике самопредстављају. ${ }^{6}$

У приповеци Лазе Лазаревића симптоматичног наслова Вериеер читање је чин аутоидентификације („како млади људи што год читају апликују на се" (Лазаревић 1986: 95) па ће се „уписивањем” лика (Гетеовог Вертера) у други лик (интелектуалаца Јанка, јунака слабе воље), проблематизовати одређен тип читалачке рецепције заснован на емотивној и менталној идентифкацији читалац=лик.

У студији Сйраgаґа млаgої Вертера J. В. Гететеа и Вертер Л. Лазаревића у светилу иниеериекстиуалних веза Ђорђе Деспић пише да Јанко читајући „у машти врши одабир оних места из лектире која треба да што снажније изазову илузију заљубљености" (2000: 139).

Већ на првим странама Јанко виде да је и он сам Вертер, и, при свакој сцени у књизи, тражаше какву сличну ситницу из свога живота. Вертерова јадиковања за само га срце уједаху, и он му у памети стискаше руку која је већ давно на небу с Лотом заједно. Све, све му се допадаше, и у свему он виђаше себе [...] И што се више примицаше крају књиге, тим се све више збратимљаваше с Вертером, и најзад, кад Вертер узима пиштоље, и Јанко погледа свој револвер на зиду, који му изгледаше као некакав сигнал, и иза њега као да види боно и бледо Вертерово лице које као да му значајно клима главом: „Тако, тако, братац, ми јадни сиротани! Љубимо, али туђе жене; поштени смо, па зато треба да умремо! Ходи!" (1986: 113).

${ }^{6}$ О овоме сам писала у студији Алхемија йривијалног̄ у комично, Анархија текста, 2011: 193. 
И док јунак у наведеном примеру, преко ситуација из књиге, тумачи себе самог (Јанково интровертно читање), у другом, јунак преко себе самог и својих аксиолошких позиција тумачи књижевног јунака. Због илустративног потенцијала навешћемо и овај одломак јер је он опозитни пример првом „интровертном” читању.

Друго екстравертно (Младеново) читање:

Младен пође замишљено превртати књигу, али му одмах падоше у очи силна места, готово на свакој страни, исподвлачена писаљком. Он поче пажљиво читати. Да ли је та места подвлачио сам Јанко, да ли господар књиге, професор Недић, то не знам али Младен, наравно, мишљаше само на Јанка. И из тих исподвлачених места он састави себи потпуну слику Јанкову, и већ му се чињаше да га познаје одвајкада. Не знајући зашто, он на једној хартијици поче правити којекакве примедбице на Вертера и увек би их најпре саопштио Катанићу: „Пази, молим те!” па би онда прочитао с усиљеном декламацијом какву бенасту Вертерову ламентацију на свет, на људе, на небо и бога, и све што видимо и не видимо. Катанић са задовољством слушаше Младенове заједљиве примедбе у којима он назва једанпут Гетеа чак и будалом (1986: 119) .

Спасавање брака врши се преко читања и разумевања прочитаног (Јанко се „учи” да другачије чита/тумачи себе) - „Понизити вертеризам у његовим очима, а дићи што друго, па ето ти изласка“! (1986: 118)

Пратимо интерпретативни распон у којем је насловни јунак Гетеовог романа, с једне стране, несрећан, љубављу обузет младић с којим се треба идентификовати и жртвовати се због неостварене љубави, а с друге, „сметењак”, „лопов” „издајица”, „отимач” („Или, ваљда, треба га извинити што га је љубав обрвала? Дабогме! Лопова - што је сиромах, убојицу - „што му је таква крв”, издајицу - што 
је плашљив, отимача жена - што је заљубљен. Па онда нам није нико крив, али остајемо без части и поноса!" (...) (1986: 124)

О значају Лазаровићеве пародије Душан Иванић је писао:

Лазаревићев Вериеер је једна од најсложенијих, најексплицитнијих рецепција неког страног књижевног дјела у српској прози, у поступном појачавању пародијске и изобличујуће компоненте. Али ни овај пут то није пародија Гетеовог романа, већ његове функционалне рецепције: Јанко, заљубљен у туђу жену, роман чита као упутство за понашање, образац рјешења сопственог проблема; за Катанића - књига/роман је средство спасавања пријатељеве брачне хармоније; за мужа је могућност да понизи учеснике љубавних заноса и свог такмаца око жене, те постиже да му могући супарник постане пријатељ [...] природа пародичног говора је у Лазаревићевој прози изокренута: говор погађа јунаке и њихово разумијевање сопственог и туђег бића, а не погађа туђи текст. (Иванић 2007)

Лазаревић преко поменутих читалаца, прецизније типова читалаца, демаскира „погрешно читање” контрастирајући интровертног и екстровертног читаоца.

Трећи пародијски „калуп” везујемо за Епски модел света.

Приповетка С. М. Љубише Кањош Мацеgоновић за епски претекст може имати песму Краљевић Марко и Муса Кесеиија (сижејне паралеле су очигледне); Ипак реалистичка атрибутизација није само једна врста „пребацивача" епског сижеа (шта би било кад би се трговци нашли у позицији да буду јунаци, а Турци постали урбани декадентни Млеци), већ и стварања антитекста. Тако се херојски чин (кроз перспективна померања Црногорци : Млечани) реинтерпретира у самоубилачки чин, епска усамљеност 
јунака пред битку „Остаде Кањош сам”, у „конформистичку” колебљљивост: „Могло ми је бити да сједим дома”, херојски императив (изаћи на мегдан) у неразумност и помаму: „Нанесе ме неки гријех да овдје лудо погинем, пак да је за кога ни по јада, но за ове страшиве и надуте ниткове". Уместо спасавања слабих, незаштићених девојака, сиротиње раје или заробљених побратима, у пародијској инверзији спасавају се „страшиви и надути ниткови”. Проблематизује се и избор јунака који креће на мегдан - Кањош је изабрани јунак, али не зато што је он изузетан (јунак „бољи од нас”) већ зато што „други не би умио ни доћи до дуждева двора за мјесец". ${ }^{7}$ Ипак, упркос деконструкције стабилног епског јунака, Кањош Мацедоновић није пародијски „снижени” лик. Уместо у пародију, смештамо га у парадокс. Његова снага је у апсурдности обичног човека (трговца) који постаје јунак а да то не жели да буде (он не тражи јуначке атрибуте нити трофеје који му као јунаку припадају).

Један од „канала” којим се епска слика света тривијализовала била је и њена позоришна реинтерпретација (в. приповетке Пуйујуће gрушишво Стевана Сремца и Позоришйе у йаланци Радоја Домановића). Навешћемо рекламу/објаву представе у којој се детронизује епски сиже - a глума приближава циркуској представи. Пред окупљеним мештанима провинцијског градића објаву чита глумац обучен у Милоша Обилића, а карте наплаћује седи Југ Богдан и царица Милица.

${ }^{7}$ И у Крађи и йрекрађи звона долази до декодирања епских места: припреме јунака за бој, заклетва пред битку, сама битка. У контранаративу јунаци су лопови који своју храброст доказују крађом. 
Данас увече, у два по турски, у осам по јевропски, представљаће се у Матиној башти Бој на Косову. Ту има да се види ово:

Прво: Како су се због жена својих посвађали и мејдан делили зетови цар-Лазара: Милош Обилић и Вук Бранковић, и Милош победио Вука [...] И пето: Има да се види како Милош Обилић убија цара Мурата, распорив га ножем „од учкура до бијела грла”, усред турске војске од триста хиљада! То има да се види. На крају ће бити величанствен ватромет и бенгалска ватра (Сремац б.г. 281).

У Домановићевој приповеци Позоришиее у йалани, епски предложак се такође тривијализује глумачком интерпретацијом: „а глумица у улози царице Милице се понела, да јој не можеш ни прићи. Цеди кроз зубе кад говори, дигла главу, трепће, успија с устима и с војводама се понаша као кад ноћу пред капијом крадом од госпође, говори с драганом [...] Глумац игра Милоша, па кад се продере јаче, султан бунован скочи с шиљета, једва се разбере где је, па седне опет. Публика се смеје, готово и не чује шта говоре" (Домановић 2009: 64). Историјска драма о боју на Косову пародијском интерпретацијом (глумом) трансформише се у комедију у којој глумац који игра Милоша бежи с позоришном касом са представе у кључној сцени у којој треба да убије Мурата или царица Милица постаје водвиљска јунакиња.

У Домановићевој сатири Краљевић Марко ӣо gруі̄u $\bar{u} у \bar{u}$ међу Србима пародија епског јунака удружује се са гротеском: уместо градирања епског јунаштва највећег српског јунака градира се његово дезертерство (Краљевић Марко престаје да се бори, узалудно се прилагођава јер га неепски свет избацује из себе и затвара у лудницу; на крају он не умире херојски - он једноставно „пресвисне”, поражен, 
„разочарани намучен” (метаморфоза хероја у скитницу, вампира, убицу, робијаша, пандура, лудака). Туђи текст наспрам контекста у том смислу, функционише једнолинијски преко оса јаких опозиција (контраста): епски:неепски, неприлагођен:прилагођен, традиционалан:модеран; херојски:кукавички, етичан:ненетичан, искрен:лажљив и сл. Пратимо трансформацију хероја у нехеројском свету. Он умире јер „не могаше поднети” ударце Срба, који га спроводе у лудницу. Србби, не Бог (стари крвник), убијају, код Домановића, свог највећег јунака.

Треба имати на уму да је лик Краљевића Марка и у епској традицији сложен и амбивалентан и да је и у самој традицији он већ био лик „начет” пародијом. Много је респектабилнији однос према Милошу Обилићу који се везује за косовски бој и који припада другом типу јунака (оклеветани јунаци жртве).

У пародији се непрестано оставарује једна врста комичког рецепцијског шума између туђег текста и новог текста. Она своју енергију црпи управо у тој „нелагодности" немирења са хоризонтом очекивања формираним над туђим текстом. И на језичком (десетерац: административан говор), и на сижејном, и на жанровском плану, као и у концепцији ликова, Домановић ствара контранаратив, профилише антимитски свет. Симулацијски је и патриотски говор о спасавању Косова у којем Јакшићеви стихови постају знак испражњен од првобитног значења; на фону патриотског говора јунака конструише се антиговор (кукавички и лицемерни говор) и антијунак (егоистични малограђанин).

Рецепција Домановићеве сатире указује на сложеност питања шта пародичар/или кога пародичар пародира. У анализи приповетке Краљевић Марко йо gруї йуй међу Србима, Богдан Поповић осуђује оне који сматрају да је „наш народни јунак у овој причи понижен”. Ипак, Марко 
Краљевић јесте деконтекстуализован - продијски премештен из епске песме у фарсу у којој се јунаци базично не сналазе, не разумеју друге нити друге њих, покушавајући да се снађу све више упадају у проблем, доследно греше. Комичне погрешке су ситуационе и вербалне и условљене временским измештањем јунака: нити он може да препозна нове вредности заједнице и њену реторику, нити она више може да „оживи” херојско време. Индикативно је обраћање „малог журавог човечића упалих груди, тупа погледа” који „кашљуца при говору, а руке му као штапићи”, који се епском јунаку обраћа: „говорите тише јер стојите пред влашћу". (У комичној пародијској инверзији - уместо пред турском влашћу (као султанов заточеник), Марко стоји пред српским чиновницима и полицајцима који ће га спровести у срйски затвор.)

ЧЕТВРТИ КАЛУП: ЦИТАТИ ИЗ БИБЛИЈЕ ИЛИ ЦРКВЕНЕ ЛИТЕРАТУРЕ. овај тип цитата је пародијски деконтекстуализован.

У роману Бакоња фра Брне тематско-мотивске структуре карактеристичне за религиозну књижевност пародирају се. Такви су, на пример, мотиви богоугодних и благочастивих родитеља, божјих изабраних слугу, аскезе, скрушености, монашког целибата. Пародирају се црквени жанрови - црквена хроника, житије, молитве, песме захвалнице, проповеди. Матавуљ ствара паралелни антижанр (Брнине исповести, Брнина песма „захвалница Богу"). Стварање паралелелних међусобно опонентних семантичких структура нарочито добро илуструје жанровска измештања одређених мотива (и шире сижеа) карактеристичних за црквену књижевност у нови контекст (епски, реалистички, хумористички). Нарочито је занимљива оксимеронски жанровски спој реалистичког биографског романа и житијне схеме која је сугерисане 
појединим насловима (Бакоња фра Брне, њеі̄ово ђаковање

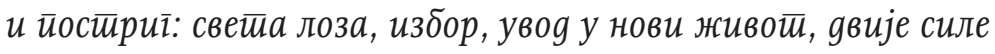
којима йоллијежу љуяи, Фра Јерковић 25).

Пародија се препознаје и у набрајању надимака фратара (цитатни алузивни предложак би могло бити набрајање Аврамових потомака). Пародирање житијног обрасца везујемо и за мотив ожалошћених родитеља чије дете напушта чулне благодети овоземаљског живота. Одлазак у манастир, парадоксално, управо представља тријумф плотског, улазак у свет ситих докоњака. Матавуљ градацијским поступком серију примера (егземплума) жанровски преозначава у антиегземпл о Бакоњи. ${ }^{8}$

И у Причањима Вука Дојчевића црква и њени симболи (нарочито спољашња обележја религиозности) мета су хумористичко карневалских преозначавања. Ипак, хумористичко код Љубише и хумористичко код Матавуља се разликују: иако је код обојице присуство пародије мање манифестно, будући подређено клици комичног, која се развија више из комичних слика и из анегдотско-комичних ситуација.

\section{ПЕТИ КАЛУП - СЕНЗАЦИОНАЛИСТИЧКА ПРЕВОДНА ЛИТЕРАТУРА}

У приказу Рукавище, романа из енглеског друштвеног живота, Андра Николић се критички осврће на „веома трогателне и пикантне приповетке” које су објављиване у Bugoвgaнy: „Романи које је издао Видовдан тако су налик један на други да је сасвим свеједно за нашу цељ, ако узмемо ма који од њих за данашњи наш књижевни преглед" (Николић 1938: 103). И док А. Николић критикује некорисност превода, избор ликова и немотивисаност радње

${ }^{8}$ O овоме смо опширније писали у студији Релиїиозне темеме - Майавуљево зрно вере, у: Огледавања - Лаза Лазаревић и Симо Матавуљ из које смо преузели овај одломак. 
(тј. мотивацију случајем $)^{9}$, у приповеци Злайна жииа Илије Вукићевића овакве проза се пародира кроз објаве:

Објава романа Злайна жииа:

Ново! Ново! Ново! Златна жица, најновији роман у осам глава.

Овај је један страшан догађај сам злочин! На сваком листу смрт! Има 10000 лица и половина гине... Сам је писац полудео... (Вукићевић, књ. 1, 318)

У наставку се описује читалачка еуфорија (читаоци који једни друге гризу), пародијски контекстуализују наслови поглавља, а затим наводи објава конкурентског романа који подиже читалачки праг реаговања на насиље:

Најновије!

Сребрна жица.

Ово је најстрашнији, најужаснији, најгрознији роман на свету. Овде је у сваком реду смрт. Сам је писац умро... сахрањен... и опет оживео.

!!! Пет пара број! Свеска само један грош!!! (Вукићевић, књ. 1, 325)

Реалистички критичари, нарочито они програмски оријентисани (Андра Николић, Пера Тодоровић) рано су реаговали на сензационалистички тип књижевности неретко дефинишући поетику реализма као њој опонентну. Тако се у епоси реализма могу пратити „критичке пародије", с једне стране, а с друге стране литерарне пародије - сензационалистичка литература се подривала и кроз

9 „Неретко, и на жалост за нашу књижевност, роман је пун и препун тајних прстију, руку, мигова итд. И та чудноватост што вири из сваког момента, та тајанственост што обавија целу радњу све до последњих листова, то и чини те читалац може да прочита сав роман. Али кад га прочита? Колико год није гадљив мора бити љут" (Николић 1938: 103). 
критику и кроз фикцију. Ипак, она је опстојавала, будући да су је писали чак и они који су је критиковали (Тодоровић).

\section{II}

Идући трагом најчешће пародираних типова текстова у епоси реализма и конкретних рецепција (како један писац чита другог или друге), после класификације пародијских „калупа”, прелазимо на ширу књижевноисторијску контекстуализацију пародије. Један поднаслов поглавља који следе могао би да гласи: Дијахронијски

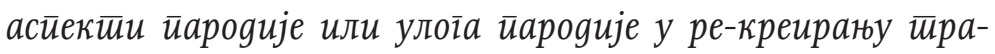

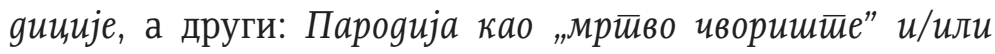

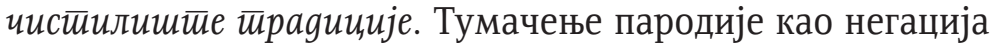
одређене традиције тема је другог дела нашег рад.

У покушају да књижевноисторијски профилишемо пародију у епоси реализма, окрећемо се уназад према текстовима које су реалистички писци могли да читају. (0 сервантесовском и гогољевском моделу као доминантним моделима пародијских текстова „усвојеним” из стране књижевности писали смо и ми и други историчари књижевности. Задржаћемо се стога на месту пародије у контексту српске књижевности издвајајући као парадигматски тип текста Стеријин роман.)

Роман без романа се може назвати српским мета-романом 19. века. Он је синтеза, акумулација доминантних традиција писања романа, колико и њихова негација. У поређењу са делима која ће доћи, Стеријин роман ће имати већи пародијски интензитет. Зато њега узимамо као најрепрезентативнији тип пародијског текста из 19. века који је имао јак утицај на традицију/наставак пародијског писања. Драгиша Живковић пише да је Стерија 
извршио „најкрупнију и најзначајнију стилску промену у српској литератури: уместо плачљиво-сентименталне, моралистичке и просветитељске прозе типа ВидаковићАтанацковић, он започиње нову оријентацију на хумористичко-пародично виђење света и дотадашње литературе" (Живковић 1982: 249). По мишљењу Живковића, на ову линију се надовезује Игњатовић, Трифковић и Сремац (Живковић 1982: 249). Стерија је својом пародијом трасирао пут српске реалистичке књижевности. „Калупи” који су пародирани у његовом Роману без романа - у реализму су поновљени, само је начин и интензитет пародирања био другачији. Душан Иванић запажа да се стога у реализму пре може говорити о пародичности текстова („фрагментацији пародије"), додали бисмо о пародији у тексту, а не о тексту-пародији какав је Стеријин Роман без романа (Иванић 2007: 127)

Код Игњатовића пародијска рушилачка енергија се повлачи пред лажном лакоћом водвиљског света, код Сремца - пред причом о новом свету и новим односима у друштву. У поређењу са Стеријом, Игњатовић и Сремац не стварају антироман, већ нови тип реалистичког друштвеног и хумористичког романа. Сремчев Пой Ћира u $\bar{u} о \bar{u}$ Сйuра истовремено је и породични и љубавни роман, и хумористички и меланхолични. У њему су успешно укрштени раздвојени низови - роман као хроника породице (Игњатовић), са пародијом љубавног романа (какав су писали Стојковић, Атанацковић, Видаковић), хумористичко публицистичком књижевном традицијом (Змај), преводном књижевношћу (Гогољ, Дикенс) и изразито присутном усменом књижевношћу. Заједничко свим писцима је што пародија у њиховим делима не покреће једну асоцијативну везу (текст против текста) већ густу мрежу интертекстуалних веза и односа који могу бити имитативни, конкурентски, симболички, метонимични и сл. 
Из пародијских модела може се реконструисати реалистички хипотетички непожељан текст. Чине га: историјске, сензационалистичке или патетичне повести у којима су јунаци изузетни по својим способностима и радикални у својим емотивним изборима. То су текстови у којима доминира мотивција случајем или удесом, изразито фабулативни са многобројним подзаплетима али са жанровски предвидљивим расплетима (случајни и кобни, било позитивни или негативни сусрети; препознавање преко тајанствених предмета; неочекивани тестаменти; отмице и промена вере). Одликује их повишена реторичност, а доминантне стилске фигуре су хипербола, метафора и градација.

Из пародијских модела може се реконструисати и пожељан реалистички текст: он је у великој мери кореспондирао са очекивањима критичара - писати о савременим друштвеним темама на објективан начин, о типичним јунацима следећи законе логике и вероватноће а на ползу читалаца; језичке стилизације усмерити према миметички уверљивом говору - и максимално неутрализовати артифицијелан стил (избећи „извештаченост”).

Наша књижевноисторијска периодизација и упоређивање текстова преко пародије као и стварање хипотетичких пожељних и непожељних (пародијским трансфомацијама подложних текстова) било је одређено неколиким чиниоцима. Зависно од тога који је тип литературе био у функцији „сервантесовског витешког романа”, дијахронијски смо сагледали пут српске књижевности. После сентименталистичког модела писања, на оси пародираних смењивали су се текстови који су репрезентовали: „сладак стил”, „немачку чувствителност”, романтичарску наглашену реторичност, као и епску патетику. Путеви пародије су заправо путеви који разобличавају и уобличавају књижевна померања и откривају дијахронијска смењивања 
центра и периферије. Душан Иванић запажа: „У почетку епохе српског реализма, пародија је нападала старе, искоришћене технике, сижее, мотиве, стил, снижавала их и исмијавала. Током реализма, у његовој високој фази, помоћу пародичних релација провјерава се живот, квалитет неке животне приче, јунака или емоције. Реалисти признају у начелу или прећутно примат живота над текстом: живот је извор и мјера текста (текст треба да слиједи живот)" (Иванић 2007).

Успостављајући нове релације између текстова, пародија формализује нове хијерархијске везе међу њима - све што може добити призвук традиционалног, регулативног, инстиционализованог пропушта кроз увеличавајуће стакло; од дестабилизатора, постаје и катализатор промена у рецепцији књижевних дела, начин онеобичавања традиције, стварање новог. Пародија отвара пут маргиналном, ексцентричном, локалном, индивидуалном. Не треба притом губити из вида чињеницу да је већ током епохе реализма и сам реалистички текст постао мета пародичара. Нарочито ће се код Сремца, Вукићевића и Домановића као мете пародије појавити „стабилизатори” реалистичности: ауторитативна свезнајућа приповедна инстанца, хронотопично одређење јунака, вероватноћа заплета, логички след догађаја, експлицитна мотивација уопштавајућег типа, речју, миметичност ће бити „нагрижена" новим схватањем текста.

III

У трећем делу рада, са поетичке ауторефлексије, са ширих књижевноисторијских аспеката пародије, прелазимо на још шире, друштвеноисторијске аспекте. На трагу смо Линде Хачион која пише: „Али желим да докажем да 
управо пародија, која, како се чини, интровертира формализам - изазива директно суочавање са проблемом односа естетике према свету значења који је спољашњи по себи, према дискурзивном свету друштвено одређених значењских система (прошлих и садашњих) - другим речима, према политичком и историјском" (Хачион 1997: 49). У нашем раду пародију доводимо у везу са „светом значења које је спољашње по себи" - у везу са имитативним моделима културе, слабљењем патријархалног и нестанком херојског света.

Полазимо од књижевних чињеница да су најстарији српски романи, настајали на самом почетку 19. века, а да већ 30-ак година касније са Стеријом почиње експанзија пародијских текстова. Привидну нелогичност да се унутар културе са неразвијеном романескном продукцијом врло брзо јављају пародијски облици доводимо у везу са ширим културноисторијским контекстом српске књижевности која се у првој половини 19. века великим делом стварала у окриљу других држава и њихових доминантних културних модела.

Да бисмо аргументовали нашу тезу да је пародија настајала као један вид реакција на имитативне обрасце који се нису јављали само у књижевности, већ шире у култури, фокусираћемо се на двојезични, немачко-српски Мали речники из $1793 .{ }^{10}$ Овај речник је био намењен Србима који су се адаптирали на нови културни миље (живот у Хаб̆сбуршкој монархији) и поред пописа речи садржавао

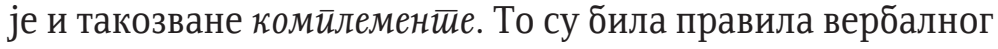
понашања у свакодневним ситуацијама: „кад један дру-

${ }^{10}$ На Мали реиник нас је упутила, комплементе проследила и о речнику с лексиколошког аспекта писала Рајна Драгићевић (2015: 113-128). О говорним жанровима и комплиментима писала сам у раду посвећеном негацији као конституенту пародије (Вукићевић 2018: 107). 
гога сусретну”, „звати кога на шпацир”, „госте к седанију принуђавати"...

Трећи комитеменй

Каg јеgан gруі̄оі̄а сусрейне

- Слуга, Господине!

- Ја сам Ваш слуга. Како на дому (код куће) Господине? А особљиво господин отац? Како се он находи?

- Он се посредствено находи.

- А госпођа мати? Ели такођер здрава?

- Што се моје матере дотиче, она је сасма злочестаго здравља.

- Мене њена немошћ верло оскребљава. Зато желим, што би она скоро опет оздравила.

- Ја захваљујем (благодарим) Господине, за таковое Ваше доброе желаније. Бог да сачува (сохранит) сву Вашу фамилију (род) у добром здрављу.

- Такођер и ја Вам исто то желим. От сердца.

\section{Шестии комйлеменй}

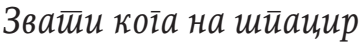

- Мој господине! Ви се непрестано трудите.

-Не баш сасма господине. Ово теке бива да ја сам себи нечто посла задајем.

- Ја нећу Вас у Вашего дела задержавати.

- Моја дела нису баш тако нужна (од потребе). Ја у ова три дна нисам из куће изишао и врло се радујем што Вас код мене (код себе) видим.

- Видећи ја господине да се време тако пријатно и красно показало јесам к Вам дошао намерен Вас упитати? Не извољевате ли и Ви на шпацир (шетање) изићи? (прошетати се)

- Господине, Ви ми с тим великују љубав показујете: зашто ми је и тако код куће дуго време читаво сам бивајући. А и моја дела не изискавају сасма великују хо- 
тишћ. Ја могу свагда прилику за моје дело наћи, али се не могу чести Вашего љубезнаго дружества свагда удостојати.

\section{Деветии комитлеменй}

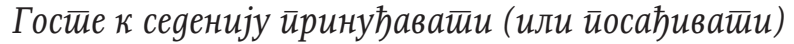

- Господине Советниче! Изволте не одрећи се овде сести (посадити се).

- Ви ћете ме утешити ако ме с тим поштедити.

- Ми се нећемо свађати.

- Молим покорњејше узмите ово место.

- Ја нећу то никако учинити. Ја седим овде врло добpo.

- Али онде можете много бољше седети.

- Опростити дакле господине ја ћу себи место овде узети. А Ви изволте онде посадити се.

- Господине! Седните без церемоније. Округли астал нејма перваго (началнаго) места. А к тому Ви ћете свагда оно место где ћете сести началное учинити. Дај да не губимо време с церемонијами, јело ће се охладити.

Намерно смо цитирали више комплимената, јер нам је задатак да покажемо како се овај тип говора који се сматрао репрезентативним у једном тренутку, уместо да се имитира - пародирао. Имајући на уму „комплементе”, анализираћемо говорне жанрове (поздрави, разговор за столом, удварање) који су прешли пут од имитације до пародије. Индикативни су следећи дијалози изабрани из романа Милан Наранцић, Стеријиног настављача, Јакова Игњатовића.

А) литераризација „комплемената” који се односе на поздраве: 
- Господин Милан Наранџић, спаија, ове друге познајете, ово је опет, госпођа Милеуснић и фрајла Отилија - Чика представља.

- Драго нам је.

- С моје стране особита чест.

- Изволте сести. (...)

- Драго ми је особито.

- Господин Милан Наранџић, спаија.

- Господин Зоричић, учитељ овдашњи и мој добри пријатељ.

- Драго ми је.

- Мени такођер... (Игњатовић, 1900: 291)

- Ево Бранка, Чико, што сам ти о њему приповедао!

- Драго ми је особито! Имао сам срећу млого свашта којешта о вама чути - рече Чика са комплиментом.

- Ово је Чика! Не знам да ли га познајеш. Честит муж!

- Имао сам част млого добра о Вами слушати.

Рукују се. (Игњатовић, 1900: 332)

- Дођемо до једне лепе велике куће. Десић каже да ту седи госпођа Ливија. Покуцамо на врата и уђемо унутpa.

- Драго ми је особито!

- Господин Наранџић, господин Чика-Голубовић...

- Драго ми је! Изволите сести! Господина Наранџића већ одавна имам срећу познавати, па да сам га само видла, одма би га познала! (Игњатовић, 1900:340)

Куртоазно позивање госта да седне на одређено место за столом, његово куртоазно одбијање, поновни позиви и одбијања, били су део друштвене игре коју је у почетку требало савладати. Временом, оно што је имало позитивни културолошки предзнак (бити адаптиран, прихваћен као део нове средине), попримило је негативан предзнак - исти говор, сада је указивао на извештаченост и/или од- 
нарођеност. Од наглашене имитације до пародије - лакше је било учинити искорак, него од говора који се није препознавао као извештачен, стран, непотребан, који се доживљавао као аутентичан.

Наведени поздрави имају пре свега инаугурални карактер, означавају улазак јунака у нову средину. Истовремено, Игњатовић разоткрива кодни систем културног понашања Срба у Хабсбуршкој, потом и Аустроугарској монархији. Игњатовић, дакле, драмски конципира јунаке у сценама сусрета не само да би фикционализовао безначајност тих сусрета (што му је Скерлић замерао), већ напротив, да би указао на њихову театралност, и разоткрио маске углађености, лажност хијерархијских сталешких или мушко-женских односа.

Пародирају се и сцене обедовања. Попут сусрета и поздрава, и оне се могу посматрати као мале фабуларно целовите јединице, серије сличне структуре. Игњатовићеви јунаци више једу и планирају него што осећају и размишљају. По томе су блиски пикарима. Кроз разговоре за столом такође се опонаша знаковно понашање сталежа који је нестајао, дочарава трошност света заогрнутог симболима лажног племства и младе грађанске класе у успону која је била сва у напорима имитације оних који су сталешки испред ње.

Сви седнемо, и сви онако штајф владамо се. Сви су били познати, ал због мене морали су мало етикецију изводити. Сад један, сад други што прослови, ал ни код једног смисла нема, није ништ интересантан разговор. (Игњатовић, 1900:392)

Индикативни су следећи одломци:

- Високородни господине, то је ретка срећа, баш фала г. Десићу што вас је овамо довео! 
- О, молим вас, немојте ме јако титулирати, јер ја, макар да ми то и компетира, опет волем да се без политике, братски разговарамо. Знате, ја се само у оваком кругу добро осећам, верујте ми зато и бегам из вароши, да се мало уклоним од комплимената. (Игњатовић, 1900: 256)

Сви седнемо, и сви онако штајф владамо се. Сви су били познати, ал због мене морали су мало етикецију изводити. Сад један, сад други што прослови, ал ни код једног смисла нема, није ништ интересантан разговор. (Игњатовић, 1900: 392)

Трећи тип пародираних „комплемената” везујемо за говорни жанр удварања. Пратимо конверзацију Милана Наранџића у друштву у којем се наизменице удвара присутним дамама:

Час се са млађима разговарам, па се опет Јованки окренем.

- Фрајлице, ви имате неки особити манијер који човека врло усхићава, ваше мирне црте на лицу показују неки особити солидитет, али кад погледам на ваше меланколичне очи, које ваше срце као кроз два огледала показују, онда не могу веровати да вам и душа кадикад не волнује, а ваша фина бледоћа, коју би какав блазиран човек могао узети за угашен пожар вашег чувства, показује ноблес вашег рода и воспитања; благо оном који би код вас ероберунг начинити могао (Игњатовић, 1900: 221).

Претерана манифестност знаковног колико ствара ефекат комичног (театралног), толико истовремено одаје и трагичност света који изумире. У строго хијерархизованом свету пуном празних симбола једног царства на умору, јунаци нису револуционарни, они су само сналажљиви; они се попут пикара добро прилагођавају, маскирају 
и мимикрирају. Иза обичних рукољуба или неинтересантних конвенционалних разговора за столом, Игњатовић је откривао свет препун лажних представљања, прерушавања, претварања, свет који ће убрзано због своје извештачености нестати.

Од Стеријиних милобрука, његових комедија и Романа без романа преко Игњатовића или Сремца пародирао се однарођен тип јунака - покондирен, полубразован, од традиције, свог језика и порекла отуђен. То је био фикцијски бунт усмерен против доминантних страних културних модела. У приповеци Л. Лазаревића Швабиu,a - кроз причу о пансионатском дружењу студената из различитих земаља, креирали су се и одређени стереотипи који су „преносили” искуства самог аутор. Јанко се не јавља само као потенцијални Вертеров литерарни клон, Лазаревић преко приче о књизи прича причу о сукобу култура. Упућујемо и на аутобиографске рефлексе приче - Лазаревићев боравак у Берлину и доживљај немачке игноратности и непознавања српске културе, хетероимаж нације која је после војних успеха развила аутостереотип културно доминанантне нације и склоност ка милитаристичком решавању проблема. У приповеци Вершеер сам приповедач упућује на одређена места у Гетеовом Верйеру која су „места себичне филозофије”. У интерпретаицији Ђорђа Деспића „овакве пристрасне интервенције биле (су) под снажним утицајем како идеја Светозара Марковића о дидактичкној функцији књижевности тако и страха пред бројним трагичним судбинама

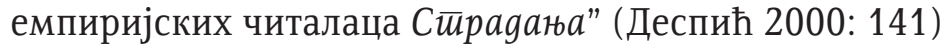

Преливање моћи пародије и њено улажење у сферу емпиријског, животног можемо пратити и у пародизацији епског калупа. Епски патријархијарални, патрилинеаран модел је у великој мери био модел према којем су се реалистички писци декларативно одређивили - иако се за- 
друга (као узорити модел патријархалне заједнице увелико распала - они су је утопистички пројектовали у својим текстовима као пожељан модел), појаву феминизма су тумачили као вид екцесног неодрживог и будаластог понашања (изузетак је социјалистички оријентисан круг писаца који су следили марковићевске идеје о ослобађању женскиња); национални идеали/планови су у текстовима реалистичких писаца ипак устукнили пред сликом социјалне стварности. О једној врсти рецепцијске борбе у којој су се иза текста укрстиле две, епска и критичка пројекција историје најбоље сведочи рецепција поменуте Домановићеве приповетке - за једне, она је била недопустиво деградирање епских вредности, за друге, критика стварности и манипулисања епском реториком (позивање на одбрану Косова које је деклеративно, али не и суштинско и сл.).

Чести ратови, али и дезертерства, штабно манекенство (парадирање чиновима и одсуствање у бици), ратно профитерство, теме су које су највише кроз документарну прозу разарале епски кодификован свет. Реалистички писци су се стога нашли у позицији да епске идеале описују као обајања младости или да их премештају у „славну прошлост". Упоређујући Сервантесовог Дон Кихойа са

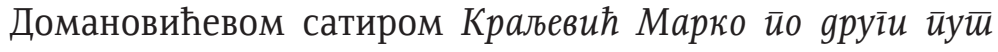
међу Србима, Јасна Стојановић пише „У Краљевић Марку Домановић је, у ствари, баш као и Сервантес, напао оно што је највише волео (...) Дубоко у себи привржен херојском духу, али разочаран због његове социјалне девалвације, он га је комично разобличио као разочарање властите младости" (Стојановић 2005: 114) . У новом свету било је немогуће ратовати као у херојском добу. Епска песма и свет који је она афирмисала - нестали су („то се само тако пева"). Ново доба је тражило нове хероје, зато се Краљевић Марко у новим околностима доживљава као Будалина Тале (в. оштру критику Данила Живаљевића који није 
имао разумевање за Домановићеву „реинтерпретацију” епског јунака).

Поље пародије се преливало преко граница текста и интегрисало у ангажовану сатиричну слику света. Процеси пародирања теку у два смера - један је у знаку афирмисања старог света (афирмисање патријархалне задруге и епске слике света; сатира усмерена према новим „измима" - феминизму, индустријализацији, капиталистичкој економији, социјалистичкој идеологији), а други ток оличава пародија која је ишла у смеру афирмисања новог света (пародирање епске слике света као неодрживе, романтичарске глорификације нације или српске историје, наглашенија европеизација културе). Индикативне су поменуте (Сремчеве и Домановићеве) приповетке у којима се на врло комичан начин дочарава сукоб између жељене и стварне позоришне публике. Да би привукли пажњу публике, иако су представе које играју од националног значаја (оне су планирно уврштене у позоришне програме), глумци су принуђени да историјске трагедије претворе у фарсе, циркуске представе. У студији Калgрма и асфалй, Дубравка Стојановић пише управо о овој „подељености” публике која је била одлична мета пародичара. С једне стране, историјске представе које су плански на репертоapy јер се њима креира прича о националном јединству и фингира публика која гледајући представу показује високу патриотску свест, а с друге стране - права публика која упркос упорном уврштавању историјских драма у програм, радије новац даје и посећује лаке, неретко стране комаде: водвиље или фарсе (Стојановић Д. 2012: 195). И код Домановића и код Сремца пародија има шире значење јер, између осталог, демаскира жељен а неодржив тип позоришта (у коме би доминирао национално-историјски репертоар) које је, по речима М. Тимотијевића, ,jедан од кључних пропагадних медија у откривању, ре- 
конструкцији, па и измишљању националне прошлости" (2005: 9-45).

Стигли смо до самих граница пародије - парадоксално, иако је пародија текст у тексту, текст-антитекст, она се шири „прелива” преко границе према вантекстовном. Наши примери показују да права пародија није само обрачуна с једним текстом, једном традицијом писања, већ и обрачун са одређеним моделима света. Чини нам се да се јавља као нека врста коректива друштвених пројекција - како оних који идеалну заједницу виде у ретроспективно утопичној перспективизацији света (критика новог, однарођеног, европеичног), тако и оних који идеалну заједницу виде у проспективно утопичној перспективизацији света (критика романтичарског етноцентризма, епске хијератичности и сл.). У ширем идеолошком контексту, пародија је реаговала на сваки облик радикализације и одвајања идеја/принципа од животне прагматике, а на реторичком, враћала текст ка необјашњивом, загонетном, значењски неухватљивом језику.

У основи нашег тумачења пародије јесте бахтиновско схватање језичког знака, пренасељеног значењими која му други дају и који речима Линде Хачион „не може бити одвојен од друштвених околности без порицања његове природе као знака. Језичка комуникација никада не може бити схваћена и објашњења мимо ове везе са стварном ситуацијом” (Хачион 1996: 143). Зато смо у раду „ширили”, усложњавали значења пародије - од пишчевог обрачуна са сопственом лектиром, преко обрачуна са традицијом до обрачуна са светом. 


\section{ЛИТЕРАТУРА}

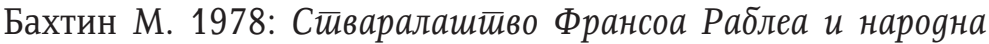
кулйура среgюеї века и ренесансе, Београд: Нолит.

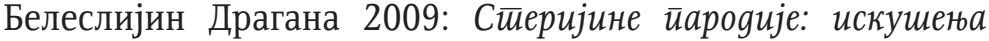

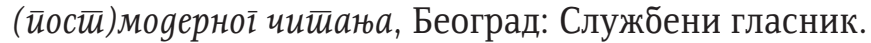

Волф В. 2006: Werner Шолф, Introduction: Frames, Framings and Framing Borders in Literature and Other Media, In: Framing Borders in Literature and Other Media edited by Werner Wolf and Walter Bernhart, Newyork.

Вукићевић Д, Милосављевић Милић С. 2014: Оїлеgавања Лаза Лазаревић и Симо Майавуљ, Ниш: Филозофски факултет.

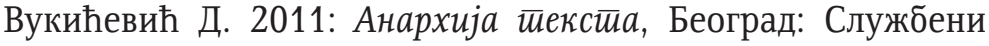
гласник.

Vukićević, D. 2018: Negotion as a Constituent of Parody in the 19th Century Serbian Novel Written in the Spirit of Cervanteces's Don Quixote, U: Od narativa do narativnosti/ From Narrative to Narrativity, Niš: Filozofksi fakultet, 99112.

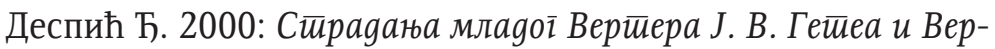

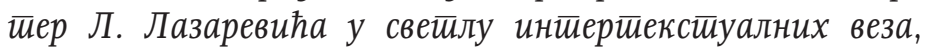
Зборник Матице српске за славистику, 56-57, 133- 145.

Драгићевић Р. 2015: О животиу и језику Срба у Хабзбуршкој монархији крајем 18. века на основу јеgної речника, Исходишта 1, Савез Срба у Румунији, Филозофски факултет Универзитета у Нишу, 113-128.

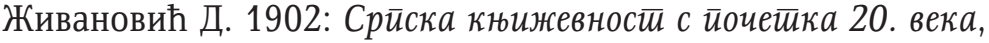
Коло, 3, 6, 377.

Живковић Д. 1970: Паробично хумористичини и иронични

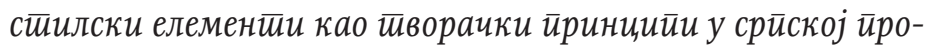
зи 19. века, У: Европски оквири српске књижевности, Београд: Просвета.

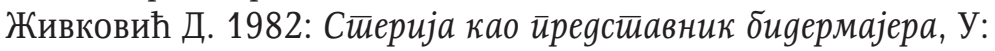
Европски оквири српске књижевности III, Београд: Просвета, 36- 55. 
Живковић Д. 1982: Периоg реализма у срӣској књижевносиии, У: Европски оквири српске књижевности III, Београд: Просвета, 246- 314.

Иванић Д. 2007: Оїлеgи о Сиеерији, Београд.

Иванић Д. 2007: Пароgија и йравестиија љьубавне ирриче у срйском реализму, Darstellung der Liebe in bosnischer, kroatischer und serbischer Literatur. Von der Renaissance ins 21. Jahrhundert: Prikazi ljubavi u bosanskoj, hrvatskoj i srpskoj književnosti. Od renesanse do danas. Hrsg. Robert Hodel. Peter Lang, s. 121-132. - Slavische Literaturen, 38.

Игњатовић J. 1900: Милан Нараниић, Београд.

Изер В. 1978: Теорија рецейије у науии о книневносиии, Београд: Нолит.

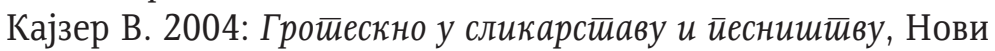
Сад.

Кестлер А. 1989: Смех иивилизованої иовека у: Књижевност, $7-8,966$.

Ковачевић М. 2002: Синйаксичка нетаиија у срӣском језику, Београд.

Лалић И.1997: О йароgијама У: О поезији, Завод, 1997, 257.

Леовац С. 1968: Сеиерија, У: Израз, 12, 6, с. 549.

Мали речник

http://digital.bms.rs/ebiblioteka/pageFlip/reader/index.php?t ype $=$ publications\&id $=184 \& m=2 \#$ page $/ 2 /$ mode $/ 2$ up Stanje 28. 04. 2015.

Манчић, А. 2010: Писања и читања превода као жанра у српским књижевним и научним часописима (поводом првих српских превода Сервантеса, Ариоста и Шекспира. Жанрови у срйској йериоgиuи. Ур. Весна Матовић. Београд: Институт за књижевност и уметност, 2010. 499-515.

Марковић, С. 1937: Изабрани сииси, Београд: Српска књижевна задруга.

Николић, А. 1938: Књижевни раgови, Београд: Српска књижевна задруга. 
Обрадовић Д. 1982: Животи и йрикљученија. Писмо Хараламüuју. Београд: Просвета. Нолит.

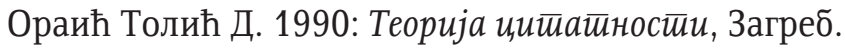

Петковић Н. 1968: Пароguја, У: Израз, јуни, 12,6, 544-548.

Поповић Б. 1968: Алеі̄орична сайирична ирича, Огледи из књижевности, Београд.

Поповић Јован Стерија, Роман без роман, In: http://www. ask.rs/ASK_SR_AzbucnikPisaca.aspxroman_bez_romana. Стање 28. 04. 2015.

Речник књиневних иеермина, 1986: Београд: Нолит, стр. 829.

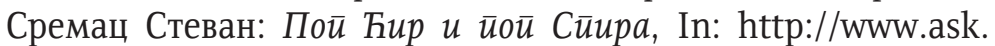
rs/ASK_SR_AzbucnikPisaca.aspxpop_cira _i _pop_spira. Стање 28. 04. 2015.

Сремац С. б.г.: Вукаguн. У: Приповетке, Загреб: Дела.

Сремац С. б.г.: Прийовейке, 1,2, Загреб: Дела.

Станојевић П. 1982: Сйрукӣура йароguје, У: Видици, 28, 181185.

Стојановић Д. 2012: Калgрма и асфалй, Београд: Чигоја.

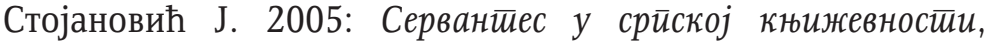
Београд.

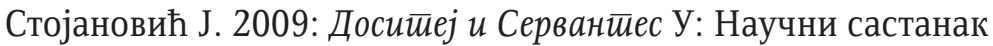
слависта у Вукове дане, 38/2, 530.

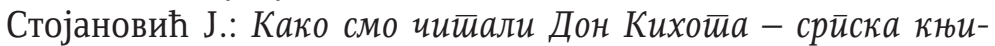
жевна кришика о Серваниеесовом роману, IN. http:// komunikacijaikultura.org/E-books/Kako\%20smo\%20cital i\%20Don\%20Kihota.pdf. Stanje 27.04.2017.

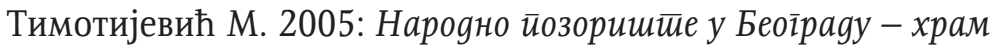
йайриойске релиіије, Наслеђе, 6, 10, 9-45.

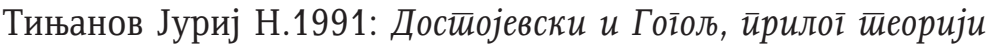
ūapoguje, У: Дело, 27, 11-12, 162-193.

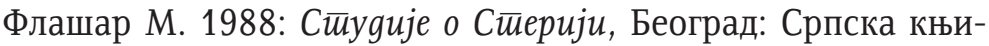
жевна задруга.

Хачион Л.1996: Поейика йостимоgернизма, Нови Сад. 
Херман Секулић М. 1989: Ка новом разумеваюу йароguje, у:

Књижевност, 5, 790-794, 6, 958-965, 7-8, 1989, 12451256. 9, 1437-1446.

Шкловски В.1969: Ускрснуће ријеии, Загреб: Стварност.

\section{Dragana Vukićević \\ PARODY IN SERBIAN REALISTIC PROSE}

\section{Summary}

In this article we considered three aspects of parody in Serbian realistic prose: A) rhetorical aspects (text-antitext, negative textual comparison, antithesis, contrast); B) historical aspects (relation to earlier traditions: parody of sentimantalistic literature - German sensuality, „sweet style”, verterism; parody of romantic conventions (romanticization of love, nation, religion); parody of realistic conventions, too; C) cultural aspects of parody (leaving the dominant cultural model).

Key words: parody, Serbian realism, citation, contrast. 